\title{
SPK PEMILIHAN JENIS TANAMAN PANGAN BERDASARKAN KONDISI LINGKUNGAN DI KOTA TIDORE KEPULAUAN MENGGUNAKAN METODE PROMETHEE
}

\author{
Anita Abdulrajak ${ }^{1}$, Salkin Lutfi ${ }^{2}$, Hairil K Siradjuddin ${ }^{3}$ \\ ${ }^{1,2,3}$ Progaram Studi Teknik Informatika, Fakultas Teknik, Universitas Khairun \\ Jl. Jati Metro, Kota Ternate Selatan \\ E-mail: anitaabdul03@gmail.com ${ }^{1}$, salkin.lutfi@unkhair.ac.id ${ }^{2}$, hairil.kurniadi@ unkhair.ac.id ${ }^{3}$
}

(Naskah masuk: 5 Juni 2020, diterima untuk diterbitkan: 16 Juli 2020)

\begin{abstract}
Abstrak
Tanaman pangan adalah bagian dari kebutuhan dasar manusia. Konsumsi pangan yang aman dan bergizi merupakan prioritas untuk mewujudkan sumber daya manusia yang berkualitas. Masalah pergantian musim yang semakin tidak menentu, membuat petani mengalami kendala untuk mementukan jenis tanaman apa yang cocok untuk dibudidayakan dengan menyesuaikan lingkungan hidup tanaman yang ada di lahan pertanian sebagaimana yang dialami oleh petani di Tidore Kepulauan. Untuk memecahkan permasalahan tersebut maka perlu untu dibangun sistem pendukung keputusan untuk memudahkan pihak terkait dalam pemilihan jenis tanaman yang tepat. Metode sistem pendukung keputusan sangat bervariasi. Pada penelitian ini digunakan metode PROMETHEE untuk memutuskan jenis tanaman pangan yang cocok untuk ditanam. Dalam mendukung keputusan jenis tanaman pangan terdapat 7 kriteria dengan 5 jenis tanaman pangan yaitu jagung, padi gogo, singkong, kacang tanah dan ubi jalar. Untuk melakukan pengujian perangkat lunak digunakan pengujian white box. Hasil pengujian sistem menunjukkan bahwa sistem mampu memberikan rekomendasi atau keputusan dengan baik untuk pemilihan jenis tanaman pangan di Kota Tidore Kepulauan. Selain itu, sistem ini berhasil diterapkan hal berdasarkan pengujian dengan white box. juga dilakukan pengujian perangkat lunak dengan menerapkan white box testing.
\end{abstract}

Kata Kunci: SPK, PROMETHEE, Pemilihan Jenis Tanaman Pangan.

\section{DSS FOR SELECTION TYPES FOOD PLANTS BASED ON ENVIRONMENTAL CONDITIONS IN TIDORE CITY USING PROMETHEE METHODS}

\begin{abstract}
Food plants are part of basic human needs. Consumption of safe and nutritious food is a priority to realize quality human resources. The problem of changing seasons is increasingly uncertain, making farmers experience obstacles to determine what types of plants are suitable for cultivation by adjusting the living environment of plants that exist on agricultural land as experienced by farmers in Tidore Islands. To solve these problems, it is necessary to build a decision support system to facilitate the parties involved in selecting the right type of plant. Decision support system methods vary greatly. In this research, the PROMETHEE method is used to decide which types of food plants are suitable for planting. In supporting the decision of the types of food plants there are 7 criteria with 5 types of food plants namely corn, upland rice, cassava, peanuts and sweet potatoes. To do software testing white box testing is used. The results of system testing indicate that the system is able to provide recommendations or decisions well for the selection of food crops in the City of Tidore Islands. In addition, the system was successfully implemented based on testing with a white box. software testing is also done by applying white box testing.
\end{abstract}

Keywords: Decision Support System, PROMETHEE, Selection of Food Crop Types.

\section{PENDAHULUAN}

Pangan merupakan salah satu kebutuhan dasar manusia. Pemenuhan atas konsumsi pangan yang cukup, aman dan bergizi menjadi prioritas untuk 
mewujudkan sumber daya manusia yang berkualitas. Akan tetapi dengan pergantian musim yang semakin tidak menentu, membuat petani mengalami kendala dalam menentukan jenis tanaman apa yang tepat untuk dibudidayakan pada kondisi lingkungan hidup tanaman yang ada di lahan pertanian.

Masalah ini dapat membuat petani mengalami gagal panen yang mengakibatkan terjadinya kerugian yang tidak sedikit. Permasalahan di atas dapat ditanggulangi dengan menggunakan sebuah sistem pemilihan tanaman pangan yang dapat membantu Dinas Pertanian dan masyarakat dalam mengambil sebuah keputusan yang efektif. SPK untuk pemilihan tanaman pangan pernah dilakukan oleh beberapa peneliti sebelumnya yaitu [1] dan [2] menggunakan data-data dari kabupaten klaten dengan metode yang diterapkan yaitu PROMETHEE.

Pembuatan sistem ini membutuhkan metode yang bisa melakukan perhitungan sesuai dengan karakteristik masing-masing kriteria [3]. Pada penelitian ini juga menerapkan metode PROMETHEE hanya data-data yang digunakan yaitu data-data dari Kota Tidore Kepulauan. Sistem juga akan dilakukan pengujian dengan menerapkan white box testing.

\section{METODE PENELITIAN}

\subsection{Sistem Pendukung Keputusan (SPK)}

Sistem pendukung keputusan adalah sauatu model atau metode dalam mendukung manusai dalam pengambilan keputusan.SPK, memilik CIBIS yang bebasl, komunikatif, dan mampu untuk menyesuaikan dengan kondisi permasalahan, metode ini dikembangkan untuk membantu dalam pemecahan masalah dan membrikan solusi. SPK berorientasi pada data, serta menyediakna tampilan yang mudah dan familiar sereta dapat menterjemahkan pemikiran dalam pengambilan keputusann [4].

\subsection{PROMETHEE}

Metode PROMETHEE adalah sebuah metode algoritma yang menitikberatkan pada penentuan urutan (perangkingan) dengan menggunakan pengambilan keputusan terhadap lebih dari satu criteria (multikriteria), dimana proses perangkkingan dirancang secara otomatis[5].

\subsection{PROMETHEE Rangking}

Untuk menghitung preferensi, maka dilakukan dengan menggunakan nilai indeks.. berikut adalah 4 langkah dalam perhitungan nilai indeks yaitu:

1. Indeks Preferensi

Mengkjur nilai preferensi dari beberapa pilihan alternative dan membandingkannya dengan alternative lain, semakin mendekati 1 (satu), semakin besar preferensinya. Jadi indeks preferensi merupakan intensitas preferensi pembuat keputusan yang menyatakan bahwa alternatif yang lainnya dengan pertimbangan secara simultan dari seluruh kriteria.

$$
\square(A 1, A 2)=1 /{ }_{K} * \Sigma(A 1, A 2)
$$

\section{Leaving Flow}

Penentuan setiap simpul dalam grafik nilai outranking adalah berdasarkan leaving flow, dengan menggunakan persamaan.

$\varphi^{+}(a)=\frac{1}{n-1} \sum_{X \in A} \varphi(a, x)$

\section{Entering Flow}

Entering Flow disebut juga Negative Outranking Flow, semakin kecil nilainya maka semakin besar dominasi suatu alternatif terhadap alternatif lainnya.

$\varphi^{-}(a)=\frac{1}{n-1} \Sigma_{X \in A} \varphi(a, x)$

\section{Net Flow}

Net Flow diukur dengan menghitung selisih Leaving Flow dan Entering Flow.

$$
\varphi(a)=\varphi^{+}(a)-\varphi^{-}(a)
$$

\subsection{Tanaman Pangan}

Tanaman pangan adalah segala jenis tanaman yang dapat menghasilkan karborhidrat dan protein. Tanaman pangan merupakan sumber makanan yang secara alamiah maupun telah melalui proses, mengandung satu atau lebih senyawa yang berdasarkan kajian-kajian ilmiah dianggap mempunyai fungsi-fungsi fisiologis tertentu yang bermanfaat bagi kesehatan. Serta dikonsumsi sebagaimana layaknya makanan atau minuman, mempunyai karakteristik sensori berupa penampakan, warna, tekstur dan cita rasa yang dapat diterima oleh masyarakat. Jadi dapat disimpulkan, tanaman pangan berarti segala tanaman yang dapat dikonsumsi oleh masyarakat, sehat, layak dan memiliki kandungan yang bermanfaat [6].

\subsection{Ciri-ciri Tanaman Pangan}

Dibawah ini beberapa kategori yang masuk kedalam kelompok tanaman pangan [7].

1. Mengandung Karbohidrat

Salah satu sumber energi bagi tubuh manusia adalah kandungan karbohidrat, hal ini mempengaruhi pola dan menu makanan masyarakat yang dalam kesehariannya mengkonsumsi makanan yang terkandung karbohidrat, hal ini tang mendorong pentingnya ketersedian tanaman pangan yang megnadung karbohidrat untuk pemenuhan energy dan gizi manusia.

2. Bisa dikomsumsi

Kategori beriktunya adalah, semua tanaman pangan yang dikembangkan seharusnya bisa dikomsumsi oleh manusia, oleh karenya harus selekif dalam memilih supaya bisa memberikan 
energy dan menyehatkan serta tidak mengandung racun.

3. Bisa untuk dikembangbiakkan (budidaya)

Untuk memperkuat ketahanan pangan, maka dimungkinkan tanaman pangan daoat dikembangbiakkan dan dibudidayakan kembali untuk mencukupi kebutuhan pangan masyarakat.

4. Bisa ditanam oleh petani

Kategori terakhir dari tanaman pangan adalah bisa di tanam kembali oleh petani sehingga bisa mencukupi kebutuhan masyrakat.

\subsection{Kondisi Lingkungan di Kota Tidore Kepulauan}

Berikut adalah data kondisi rata-rata iklim di Kota Tidore Kepulauan [8].

1. Curah Hujan

Tidore Kepulauan memiliki curah hujan 229 mm dengan durasi hujan rata-rata 6 bulan dalam 1 tahun, sedangkan suhu udara rata-rata setiap harinya adalah sedang.

2. Suhu dan Kelembaban

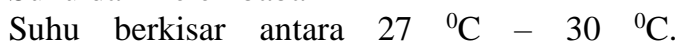
Kelembaban rata-rata adalah $22{ }^{\circ} \mathrm{C}$ dalam setahun.

3. Keadaan Tanah

Terdapat 2 (dua) jenis tanah yang ada di Kota Tidore Kepulauan yaitu tanah alufial dan tanah lempung berpasir. PH tanah yang ada umumnya bervariasi yakni dari basah, netral sampai masam 0,7 .

\subsection{White Box Testing}

White Box adalah salah satu teknik dalam melakukan uji coba terhadap perangkat lunak yang telah dibuat, sehingga detail cara penggunaan aplikasi bisa diketahui kelebihan dan kekurangan perangkat lunak. Pada metode ini terdapat basis path testing yang berfungsi untuk mengontrol agar semua jalur bisa terlewati pada saat ujicoba sistem.

Saat melakukan ujicoba system berdasarkan pada jalur yang telah ditentukan. Pada saat proses perhitungan nilai bisa menjelaskan jumlah jalur independen, dan setiap jalur diapstikan akan diekeskusi atau dilewati oleh jalur.. berikut Contoh jalur independen seperti dibawah ini [10]:

Path1:1-11

Path2:1-2-3-4-5-10-1-11

Path3:1-2-3-6-8-9-10-1-11

Path4:1-2-3-6-7-9-10-1-11

\section{HASIL DAN PEMBAHASAN}

\section{1 Perhitungan Metode PROMETHEE}

Pada tahap ini data jenis tanaman pangan dan data kriteria lahan pertanian dihitung menggunakan metode PROMETHEE. Seperti berikut:

1. Penilaian Alternatif Berdasarkan Kriteria

Adapun data hasil perhitungan atau nilai setiap alternatif seperti ditunjukkan pada Tabel 1 berikut.

\begin{tabular}{ccccccc}
\hline \multirow{2}{*}{ NO } & \multirow{2}{*}{ KRITERIA } & \multicolumn{5}{c}{ ALTERNATIF } \\
& & A & B & C & D & E \\
\hline 1 & K1 & 3 & 3 & 5 & 3 & 3 \\
2 & K2 & 3 & 3 & 3 & 1 & 5 \\
3 & K3 & 3 & 3 & 3 & 3 & 5 \\
4 & K4 & 3 & 3 & 3 & 3 & 3 \\
5 & K5 & 5 & 5 & 3 & 5 & 3 \\
6 & K6 & 3 & 3 & 3 & 3 & 3 \\
\hline
\end{tabular}

2. Hitung Indeks Preferensi Multikriteria

Setelah data setiap alternatif didapatkan maka langkah selanjutnya yaitu menghitung nilai preferensi multikriteria menggunakan Persamaan 1 . Hasil hitung indeks preferensi ditunjukkan pada Tabel 2.

\begin{tabular}{ccccccc}
\multicolumn{7}{c}{ Tabel 2. Hasil Indeks Preferensi Multikriteria } \\
\hline & A & B & C & D & E & $\sum$ \\
\hline A & - & 0 & 0,17 & 0,17 & 0,17 & 0,51 \\
B & 0 & - & 0,17 & 0,17 & 0,17 & 0,51 \\
C & 0,17 & 0,17 & - & 0,33 & 0,17 & 0,84 \\
D & 0 & 0 & 0,17 & - & 0,17 & 0,34 \\
E & 0,33 & 0,33 & 0,33 & 0,33 & - & 1,33 \\
$\sum$ & 0,50 & 0,50 & 0,84 & 1 & 0,68 & \\
\hline
\end{tabular}

3. Hitung Leaving Flow

Langkah selanjutnya yaitu menghitung leaving flow menggunakan Persamaan 2. Hasil hitung seperti ditunjukkan pada Tabel 3.

Tabel 3. Hasil Leaving flow

\begin{tabular}{ccc}
\hline No & Nama Alternatif & Nilai Leaving flow \\
\hline 1 & Jagung & 0,10 \\
2 & Padi Gogo & 0,10 \\
3 & Singkong & 0,17 \\
4 & Kacang Tanah & 0,07 \\
5 & Ubi Jalar & 0,27 \\
\hline
\end{tabular}

4. Hitung Entering Flow

Selanjutnya menghitung entering flow dari setiap alternatif menggunakan Persamaan 3. Adapun hasil hitung ditunjukkan pada Tabel 4.

Tabel 4. Hasil Entring Flow

\begin{tabular}{ccc}
\multicolumn{2}{c}{ Tabel 4. Hasil Entring Flow } \\
\hline No & Nama Alternatif & Nilai Entering flow \\
\hline 1 & Jagung & 0,10 \\
2 & Padi Gogo & 0,10 \\
3 & Singkong & 0,17 \\
4 & Kacang Tanah & 0,20 \\
5 & Ubi Jalar & 0,13 \\
\hline
\end{tabular}

5. Hitung Net Flow

Menghitung net flow merupakan tahap akhir dari penerapan metode PROMETHEE. Untuk mendapatkan nilai net flow digunakan Persamaan 4. Hasil hitung ditunjukkan pada Tabel 5.

Tabel 5. Hasil Net Flow

\begin{tabular}{ccc}
\hline No & Nama Alternatif & Nilai Net Flow \\
\hline 1 & Jagung & 0,00 \\
2 & Padi Gogo & 0,00 \\
3 & Singkong & 0,00
\end{tabular}




\begin{tabular}{ccc}
4 & Kacang Tanah & $-0,13$ \\
5 & Ubi Jalar & 0,13 \\
\hline
\end{tabular}

\section{2 Implementasi Interface}

1. Halaman Penilaian

Pada halaman menu penilain terdapat input data penilaian alternatif. Pada halaman penilaian juga terdapat pilihan melakukan perhitungan metode PROMETHEE. Dapat dilihat pada Gambar 2 dan Gambar 3.

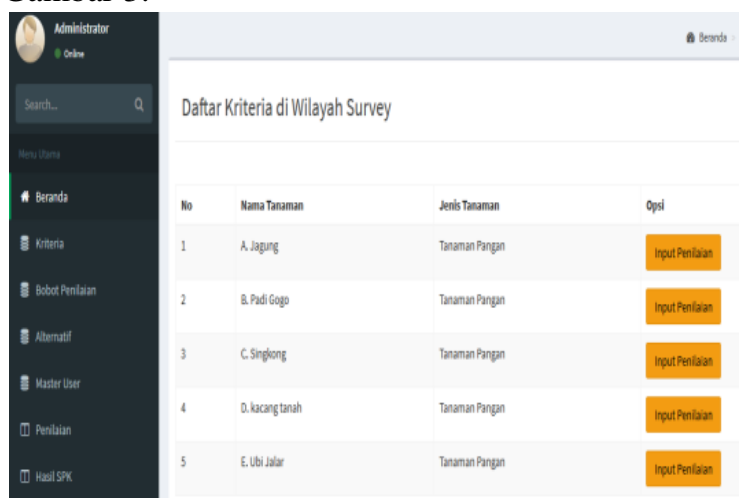

Gambar 2. Halaman Penilaian

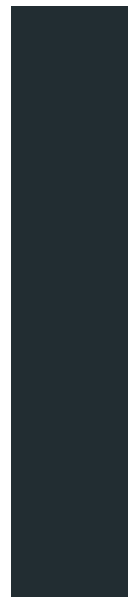

Data Penilaian Tanaman Pangan Berdasarkan Kriteria
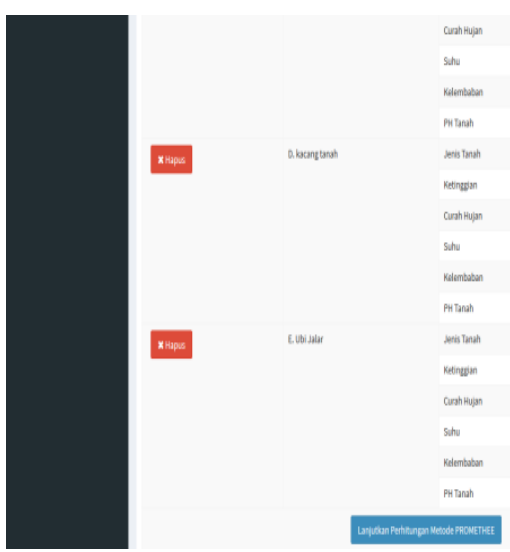

Gambar 3. Data Penilaian

2. Halaman Hasil SPK

Pada halaman menu hasil SPK, terdapat hasil keputusan dari sistem atau hasil perangkingan. Seperti pada gambar dibawh ini:

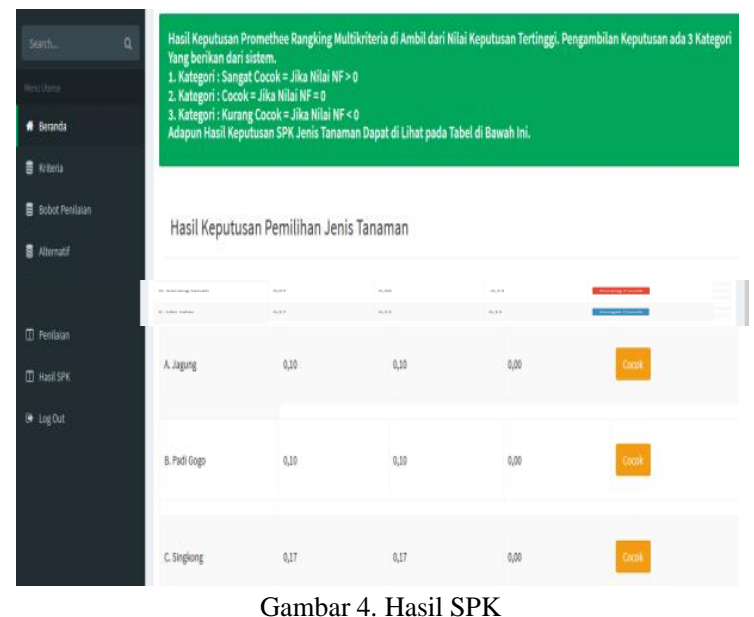

\section{3 White Box testing}

1. Modul Login

Pada flowgraph modul login diambil dari flowchart login, adapun flowchart dan flowgraph modul login seperti pada gambar dibawah ini:.

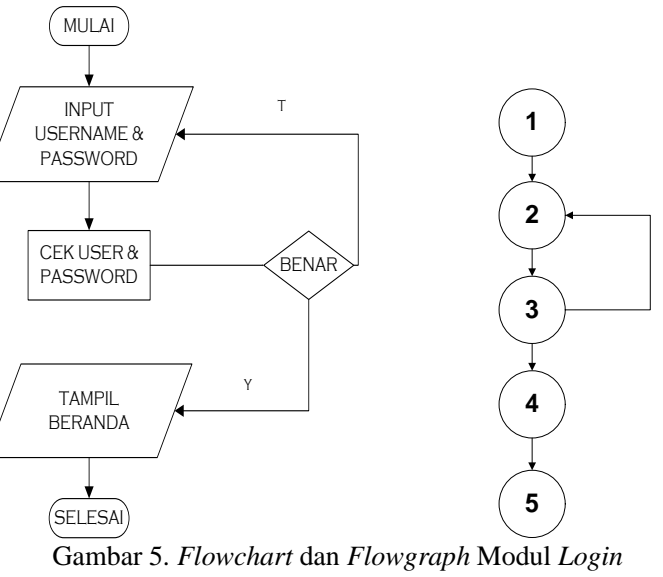

Keterangan :

Node $(\mathrm{N}): 5$

Edge : 5

Predikat $(\mathrm{P}): 1$

Cylomatic Complexcity

$$
\begin{aligned}
\mathrm{V}(\mathrm{G}) & =(\mathrm{E}-\mathrm{N})+2 \\
& =(5-5)+2 \\
& =0+2 \\
& =2 \\
\mathrm{~V}(\mathrm{G}) & =\mathrm{P}+1 \\
& =1+1 \\
& =2
\end{aligned}
$$

Independent path:

Path 1:1232345

Path $2: 12345$

\section{KESIMPULAN}

Langkah pertama pada metode PROMETHEE yaitu menentukan kriteria dimana kriteria yang dipakai yaitu jenis tanah, ketinggian, curah hujan, suhu, kelembaban, dan $\mathrm{Ph}$ tanah. Selanjutnya 
tentukan alternatif dimana jenis tanaman pangan yang dipakai yaitu jagung, padi gogo, singkong, kacang tanah, dan ubi jalar. Kemudian pemberian bobot untuk kriteria dan pemberian nilai untuk alternatif, dan perhitungan PROMETHEE yaitu menghitung indeks preferensi, indeks preferensi multikriteria, nilai leaving flow, nilai entering flow, dan nilai net flow. Untuk menghitung PROMETHEE dilihat pada nilai net flow yang tertinggi yaitu jika $>0$ maka sangat cocok, jika $=0$ maka cocok, dan $<0$ maka kurang cocok. Pada penelitian ini didapat nilai net flow untuk setiap alternatif yaitu jagung 0,00 (cocok), padi gogo 0,00 (cocok), singkong 0,00 (cocok), kacang tanah -0,13 (kurang cocok), dan ubi jalar 0,13 (sangat cocok).

Pengujian sistem menggunakan metode white box, dengan melakukan uji terhadap 6 modul pada program, yaitu modul login, modul utama KJF, modul kriteria, modul bobot penilaian, modul alternatif, dan modul penilaian. Dari pengujian keenam modul tersebut didapat total nilai independent path 24 dan total nilai cylomatic complexcity 24, maka dapat disimpulkan bahwa aplikasi yang dirancang dapat dikatakan bebas dari kesalahan logika.

\section{DAFTAR PUSTAKA}

[1]. Z. Zhai., dkk., 2020. Decision support systems for agriculture 4.0: Survey and challenges" Computers and Electronics in Agriculture. Vol. 170, pp. 1-16. https://doi.org/10.1016/j.compag.2020.105256

[2]. W. N. Adila., R. Regasari dan H. Nurwasito., 2018. "Sistem Pendukung Keputusan (SPK) Pemilihan Tanaman Pangan Pada Suatu Lahan Berdasarkan Kondisi Tanah Dengan Metode Promethee"., Jurnal Pengembangan Teknologi Informasi dan Ilmu Komputer. Vol.5 (2), pp.2118-2126

[3]. A. R. Laisouw., S. Lutfi dan F. Tempola., 2019. "Sistem Pendukung Keputusan Pemberian Bantuan Program Keluarga Harapan pada Orang Miskin di Kota Ternate Menggunakan Metode AHP", JIKO (Jurnal Informatika dan Komputer), vol. 2 (1), pp.34-40.

[4]. Turban, A., dan Liang. 2005. Decision Support System and Intelligent Systems (Sistem Pendukung Keputusan dan Sistem Cerdas) Jilid I Edisi 7: Andi. Yogyakarta.

[5]. F. H. Bajando dan Hidayati, 2018. "Sistem Pendukung Keputusan Untuk Menentukan Siswa Lulusan Terbaik Dengan Menggunakan PROMETHEE (Studi Kasus SMA Negeri 3 Pontianak). Jurnal Coding, Sistem Komputer Untan, 6(3), pp. 227-236.

[6]. Junaidah., P. Suryanto dan Budiadi., 2015. "Komposisi Jenis Dan Fungsi Pekarangan (Studi kasus desa Giripurwo, Kecamatan
Girimulyo, DI Yogyakarta)",, Jurnal Hutan Tropis. Vol.4 (1), pp.77-84.

[7]. A. Wahyudin., Ruminta dan S. A. Nursaripah 2016. "Pertumbuhan dan hasil tanaman jagung (Zea maysL.) toleran herbisida akibat pemberian berbagai dosis herbisida kalium glifosat”., Jurnal Kultivasi .Vol. 15(2), pp. 8691.

[8]. Dinas Pertanian Kota Tidore Kepulauan. 2020. Kriteria Lahan Pertanian dan Jenis tanaman Pangan.

[9]. H. K. Siradjuddin dan S. D. Abdullah., 2018. "Implementasi Prototype Aplikasi E-Lapor Berbasis Jejaring Sosial Untuk Pelayanan Keluhan Pelanggan Pada Kantor PDAM"., JIKO (Jurnal Informatika dan Komputer), vol. 1 (1), pp.27-33.

[10]. A. S. Soroto., A. Fuad dan S. Lutfi., 2018. Penerapan Metode Case Basedreasoning (CBR) Untuksistem Penentuan Status Gunung Gamalama. JIKO (Jurnal Informatika dan Komputer), vol. 1 (2), pp.70-75. 